\title{
Integrated Management of Glyphosate-Resistant Giant Ragweed (Ambrosia trifida) with Tillage and Herbicides in Soybean
}

\author{
Zahoor A. Ganie, Lowell D. Sandell, Mithila Jugulam, Greg R. Kruger, David B. Marx, and \\ Amit J. Jhala*
}

Giant ragweed is one of the most competitive annual broadleaf weeds in soybean production fields in the midwestern United States and eastern Canada because of its early emergence, rapid growth rate, high plasticity, and resistance to glyphosate and acetolactate synthase inhibitors. Therefore, earlyseason management of giant ragweed is critical to avoid yield loss. The objectives of this study were to evaluate control of glyphosate-resistant giant ragweed through the integration of preplant tillage or 2,4-D; PRE or early POST (EPOST) followed by (fb) late POST (LPOST) herbicide programs with or without preplant tillage or 2,4-D; and their effect on soybean injury and yield. A field study was conducted in 2013 and 2014 in David City, NE in a field infested with glyphosate-resistant giant ragweed. Preplant tillage or 2,4-D application provided $>90 \%$ control of glyphosate-resistant giant ragweed $14 \mathrm{~d}$ after preplant treatment. Giant ragweed control and biomass reduction were consistently $>90 \%$ with preplant tillage or $2,4-\mathrm{D} \mathrm{fb}$ sulfentrazone plus cloransulam PRE or glyphosate plus cloransulam EPOST fb glyphosate plus fomesafen or lactofen LPOST compared with $\leq 86 \%$ control with same treatments without preplant tillage or 2,4-D. PRE or EPOST fb LPOST herbicide programs preceded by preplant treatments resulted in giant ragweed density $<2$ plants $\mathrm{m}^{-2}$ and soybean yield $>2,400 \mathrm{~kg} \mathrm{ha}^{-1}$ compared with the density of $\geq 2$ plants $\mathrm{m}^{-2}$ and soybean yield $<1,800 \mathrm{~kg} \mathrm{ha}^{-1}$ under PRE or EPOST fb LPOST herbicide programs. The contrast analysis also indicated that preplant tillage or 2,4-D fb a PRE or POST program was more effective for giant ragweed management compared with PRE $\mathrm{fb}$ POST herbicide programs. Integration of preplant tillage would provide an alternative method for early-season control of giant ragweed; however, a follow up application of herbicides is needed for season-long control in soybean.

Nomenclature: 2,4-D amine; cloransulam; fomesafen; lactofen; sulfentrazone; giant ragweed, Ambrosia trifida L.; soybean, Glycine $\max$ (L.) Merr.

Key words: Preplant herbicides, preplanttillage, weed control, weed resistance management.

\begin{abstract}
Ambrosia trifida es una de las malezas de hoja ancha más competitivas en campos de producción de soja en el centro-oeste de los Estados Unidos y en el este de Canada debido a su emergencia temprana, alta tasa crecimiento, alta plasticidad, y resistencia a glyphosate e inhibidores de acetolactate synthase. Por esta razón, el manejo de $A$. trifida, temprano durante la temporada de crecimiento, es crítico para evitar las pérdidas de rendimiento. Los objetivos de este estudio fueron evaluar el control de $A$. trifida resistente a glyphosate mediante la integración de labranza en pre-siembra o 2,4-D; aplicaciones PRE o POST temprana (EPOST) seguido por $(\mathrm{fb})$ programas de herbicidas en POST tardía (LPOST) con o sin labranza en presiembra o 2,4-D; y su efecto sobre el daño y rendimiento de la soja. Se realizó un estudio de campo en 2013 y 2014 en David City, Nebraska en un campo infestado con $A$. trifida resistente a glyphosate. La labranza en pre-siembra o la aplicación de 2,4-D brindó $>90 \%$ de control de $A$. trifida resistente a glyphosate $14 \mathrm{~d}$ después del tratamiento presiembra. El control y la reducción en la biomasa de $A$. trifida fueron $>90 \%$ consistentemente con la labranza pre-siembra o 2,4-D fb sulfentrazone más cloransulam PRE o glyphosate más cloransulam EPOST fb glyphosate más fomesafen o lactofen POST al compararlo con $\leq 86 \%$ de control con los mismos tratamientos sin labranza pre-siembra o 2,4-D. Programas de herbicidas PRE o de EPOST fb LPOST precedidos por tratamientos pre-siembra resultaron en una densidad de $A$. trifida $<2$ plantas $\mathrm{m}^{-2}$ y un rendimiento de soja $>2,400 \mathrm{~kg} \mathrm{ha}^{-1}$ al compararse con la densidad de $\geq 2$ plantas $\mathrm{m}^{-2} \mathrm{y}$ un rendimiento de soja $\leq 1,800 \mathrm{~kg} \mathrm{ha}^{-1}$ con programas de herbicidas PRE o EPOST fb LPOST. El análisis de contrastes también indicó que la labranza pre-siembra o 2,4-D fb de un programa PRE o POST fue más efectiva para el manejo de $A$.
\end{abstract}

\footnotetext{
DOI: 10.1614/WT-D-15-00089.1

* First, second, and sixth authors: Graduate Research Assistant, Extension Educator, and Assistant Professor, Department of Agronomy and Horticulture, University of Nebraska-Lincoln, Lincoln, NE 68583-0915; third author: Assistant Professor, Department of Agronomy, Kansas State University, Manhattan, KS 66506; fourth author: Assistant Professor, Department of Agronomy and Horticulture, West Central Research and Extension Center, University of Nebraska-Lincoln, North Platte, NE 69101; fifth author: Professor, Department of Statistics, University of Nebraska-Lincoln, Lincoln, NE 68583. Corresponding author's E-mail: Amit.Jhala@unl.edu.
} 
trifida al compararse con programas de herbicidas PRE fb POST. La integración de labranza pre-siembra brindaría una alternativa de manejo para el control de $A$. trifida, temprano en la temporada. Sin embargo, se requiere que a esto le siga una aplicación de herbicidas para obtener un control a lo largo de toda la temporada en soja.

Giant ragweed, a member of the Asteraceae family, is a highly competitive summer annual broadleaf weed. Giant ragweed is native to the United States and known for its allergenic pollen grains that are a major cause of hay fever (Kil et al. 2004; Rybnicek and Jager 2001). Historically, giant ragweed was commonly found in noncrop areas, including stream banks, flood plains, rights-of-way, fence lines, and disturbed locations (Abdul-Fatih and Bazzaz 1979; Bassett and Crompton 1982). However, over the last 2 decades, giant ragweed has adapted to agricultural cropping systems and become a challenging weed in several agronomic crops (Johnson et al. 2006; Norsworthy et al. 2010; Steckel 2007; Vink et al. 2012a). Due to its early emergence, rapid growth rate, large leaf size, high photosynthetic rate, and ability to germinate and survive in diverse environments (Abdul-Fatih and Bazzaz 1979; Bazzaz and Carlson 1979; Harrison et al. 2001), giant ragweed has a competitive advantage in agronomic crops early in the season compared with other weed species that emerge later (Werle et al. 2014). In addition, giant ragweed's adaptation toward a wider window of emergence in arable fields, high plasticity in plant vigor, and rapid biomass accumulation allows giant ragweed to dominate over all other vegetation in its vicinity (Davis et al. 2013; Glettner and Stoltenberg 2015; Kelly et al. 2012; Schutte et al. 2008, 2012).

Giant ragweed is a major weed in corn (Zea mays L.), soybean, and cotton (Gossypium hirsutum L.) and is enumerated as one of the most problematic and economically important weeds in Illinois, Indiana, Kentucky, Minnesota, Nebraska, Ohio, and Oklahoma (Johnson et al. 2004; Jordan 1985; Loux and Berry 1991). Previous studies have evaluated the competition of giant ragweed in corn, soybean, and cotton, and indicated that giant ragweed is most competitive in soybean even at low densities (Barnett and Steckel 2013; Baysinger and Sims 1991; Harrison et al. 2001). For instance, a yield reduction of 45 to $50 \%$ has been documented with 2 giant ragweed plants $9 \mathrm{~m}^{-1}$ of row length in soybean (Baysinger and Sims 1991). Webster et al. (1994) reported up to $77 \%$ reduction in soybean yield with interference of 1 giant ragweed plant $\mathrm{m}^{-2}$. Additionally, Webster et al. (1994) documented two different growth habits used by giant ragweed to take competitive advantage over soybean at low densities. Early in the season, giant ragweed emerges rapidly and outgrows the crop in height to create a shading effect with little growth within the canopy. However, late in the season when its primary leaves begin to abscise, axillary leaves are produced within the canopy. These late-emerging axillary leaves are more shade tolerant, allowing giant ragweed to compete for light and resources not only above, but also within, the soybean canopy (Regnier and Stoller 1989; Webster et al. 1994).

The critical period of weed control in soybean is 4 to 6 wk after planting (Bloomberg et al. 1982; Coble et al. 1981; Williams and Hayes 1984); however, to avoid soybean yield losses due to giant ragweed interference, its critical period extends from 8 to $10 \mathrm{wk}$ after soybean emergence (Baysinger and Sims 1991). Harrison et al. (2001) reported 76 to $87 \%$ reduction in yield losses with a 4 -wk delay in emergence of giant ragweed in corn compared with losses with concurrent emergence. Therefore, earlyseason control of giant ragweed is essential to reduce yield losses and can provide the crops with an initial competitive advantage. Historically, acetolactate synthase (ALS) inhibitors such as cloransulammethyl, chlorimuron-ethyl, and imazethapyr were used for giant ragweed control (Franey and Hart 1999). However, giant ragweed control options were reduced within a short time frame when ALS inhibitor-resistant biotypes were reported in several states including Indiana, Illinois, Iowa, and Ohio (Heap 2015; Patzoldt and Tranel 2002; Taylor et al. 2002; Zelaya and Owen 2004).

The commercialization and rapid adoption of glyphosate-tolerant soybean after 1997 enabled producers to effectively control giant ragweed, including ALS inhibitor-resistant biotypes, with glyphosate (Stachler 2008). However, the repeated and continuous use of glyphosate in glyphosatetolerant corn and soybean resulted in the evolution of glyphosate-resistant giant ragweed. It was first 
confirmed in 2004 in Ohio and subsequently in 11 states including Arkansas, Indiana, Iowa, Kansas, Kentucky, Minnesota, Mississippi, Missouri, Nebraska, Tennessee, and Wisconsin (Heap 2015), and in Ontario, Canada (Sikkema et al. 2009; Vink et al. 2012a). The potential causes for the large-scale prevalence of glyphosate-resistant giant ragweed are the continuous use of glyphosate over several years, limited or no use of PRE herbicides, and shift toward no-till cropping systems (Ferrell and Witt 2002; Givens et al. 2009; Powles and Yu 2010; Young 2006). Moreover, since no herbicides with new modes of action have been introduced to the market for over 2 decades (Green 2014), the POST herbicide options for control of herbicide-resistant weeds, including giant ragweed, are limited (Duke 2012). Therefore, diversification of weed management programs is urgently needed. These include nonchemical options such as cover crops, tillage, crop rotation, and harvest and destruction of weed seeds to reduce weed seedbank addition (Norsworthy et al. 2012; Shaner and Beckie 2014; Walsh et al. 2013).

Historically, tillage has been one of the most important methods for weed control in agricultural crops (Shrestha et al. 2006). Tillage usually affects weeds by splitting shoots from roots, uprooting or covering unwanted vegetation, stirring weed seeds both vertically and horizontally, and modifying the soil environment to promote or inhibit seed germination and establishment (Clements et al. 1996; Shaw et al. 2012; Swanton et al. 2000). Wilson (1993) reported 86\% reduction in weed density with preplant tillage compared with a nontreated control, and observed broad-spectrum weed control by integrating preplant tillage with herbicides compared with tillage or herbicides alone. In addition, tillage integrated with herbicides has been substantial for the management of important herbicide-resistant weeds, such as Palmer amaranth (Amaranthus palmeri S. Wats.) in the southern United States (Aulakh et al. 2012; Culpepper et al. 2009; Kelton et al. 2013).

Currently, protoporphyrinogen oxidase (PPO) inhibitors and some ALS-inhibiting herbicides, particularly cloransulam-methyl, are frequently used for the control of giant ragweed in soybean (Knezevic 2015; Vink et al. 2012b). Several studies have reported effective $(>89 \%)$ control of giant ragweed with PPO inhibitors such as bentazon, carfentrazone, flumioxazin, and fomesafen (Norsworthy et al. 2010, 2011). However, dependence on herbicide(s) with the same mode of action for control of troublesome weeds, such as giant ragweed, increases the potential risk for evolution of new herbicide resistance. In addition, for earlyand late-season control of glyphosate-resistant giant ragweed, diverse strategies are needed that will allow the planting of soybean in a weed-free environment and prevent the enrichment of the weed seedbank in the soil (Bagavathiannan and Norsworthy 2012; Norsworthy et al. 2012). Scientific literature is not available on the effect of early spring tillage on the control of giant ragweed.

The objectives of this study were to evaluate an integrated approach for the management of glyphosate-resistant giant ragweed in glyphosate-tolerant soybean by determining: (1) the effectiveness of preplant tillage or 2,4-D, and (2) the relative effectiveness of PRE $\mathrm{fb}$ POST vs. EPOST $\mathrm{fb}$ LPOST herbicide programs with or without preplant tillage or 2,4-D and their impact on soybean injury and yield. We hypothesized that preplant tillage or 2,4-D fb PRE or EPOST $\mathrm{fb}$ LPOST herbicides would result in early- and lateseason control of glyphosate-resistant giant ragweed compared with PRE or EPOST fb LPOST herbicide programs.

\section{Materials and Methods}

A field study was conducted at David City $\left(41.25^{\circ} \mathrm{N}, 97.13^{\circ} \mathrm{W}\right), \mathrm{NE}$ in 2013 and 2014 in a grower's field infested with glyphosate-resistant giant ragweed. A giant ragweed biotype from this site was confirmed to be resistant to glyphosate in 2011 , with the level of resistance ranging from 14 to $36 \times$ (where $\times$ is the labeled rate of glyphosate [i.e, $1,260 \mathrm{~g}^{2} \mathrm{ha}^{-1}$ ] required for $>90 \%$ control of susceptible populations) compared with susceptible biotypes (Rana et al. 2013). The level of resistance was determined by calculating a ratio of glyphosate rate required for $90 \%$ control of glyphosateresistant and -susceptible giant ragweed biotypes. The density of glyphosate-resistant giant ragweed at this site was 18 to 30 plants $\mathrm{m}^{-2}$. The soil texture of the experimental site was silty loam with a $\mathrm{pH}$ of 5.4 , and a composition of $18 \%$ sand, $50 \%$ silt, $32 \%$ clay, and $2.1 \%$ organic matter (AgSource Laboratories, Lincoln, NE 68502). Glyphosate-resistant 
soybean seeds (Cv. 'Pioneer 93Y12' [2013] and 'NK S28U7' [2014]) were planted $3 \mathrm{~cm}$ deep on May 24, 2013 and May 17, 2014. Individual plots were $3 \mathrm{~m}$ wide and $9 \mathrm{~m}$ long, containing four soybean rows spaced $76 \mathrm{~cm}$ apart. The treatments were arranged in a split-plot design with four replications, where the main plot was preplant control methods (preplant tillage, 2,4-D, or no preplant control), and the subplot was PRE/POST herbicide treatments. A total of 12 treatment combinations, including preplant tillage or 2,4-D application, or no preplant control fb PRE or POST herbicides, was compared for control of glyphosate-resistant giant ragweed in soybean (Table 1). A treatment with no preplant tillage or herbicide application served as a nontreated control for comparison. The application rates of herbicides were selected on the basis of the labeled rates in soybean.

Preplant tillage was accomplished using a tandem disk harrow on May 10, 2013 and May 3, 2014 and 2,4-D was applied on the same day during both years. Herbicide treatments were applied as PRE (May 24, 2013 and May 17, 2014), early POST (EPOST) (June 14, 2013 and June 10, 2014), and late POST (LPOST) (June 28, 2013 and June 30, 2014). Herbicides were applied with a $\mathrm{CO}_{2^{-}}$ pressurized backpack sprayer calibrated to deliver $140 \mathrm{~L} \mathrm{ha}^{-1}$ at $276 \mathrm{kPa}$ equipped with a four-nozzle boom fitted with AIXR 110015 flat-fan nozzles (TeeJet, Spraying Systems Co., P.O. Box 7900, Wheaton, IL 60189). The experimental site was under rain-fed/dryland conditions during both years without any supplemental irrigation.

During both years, data were collected for visual control estimates of giant ragweed using a scale of 0 (no control) to $100 \%$ (complete control) at 7 and $14 \mathrm{~d}$ after preplant treatments (DAPT); 7, 14, and $21 \mathrm{~d}$ after PRE (DAPRE) herbicide treatments; 30 and $60 \mathrm{~d}$ after EPOST (DAEPOST) herbicide treatments, and at harvest. Herbicide injury symptoms on soybean (if any) were recorded using a scale of 0 (no injury) to $100 \%$ (plant death) at 7,14 , and $21 \mathrm{~d}$ after herbicide treatments. Glyphosate-resistant giant ragweed density was recorded from two randomly selected $0.25-\mathrm{m}^{2}$ quadrats per plot at 30 and 60 DAEPOST herbicide treatments and $2 \mathrm{wk}$ before soybean harvest. Glyphosate-resistant giant ragweed biomass was assessed from the same two $0.25-\mathrm{m}^{2}$ quadrats per plot randomly selected for density data at 60 DAEPOST. Giant ragweed plants that survived herbicide treatments were cut at the stem base close to the soil surface, placed in paper bags, dried in an oven for $72 \mathrm{~h}$ at $50 \mathrm{C}$, and the dried biomass was weighed $(\mathrm{g})$. Soybeans were harvested using a plot combine and yields were adjusted to $13 \%$ moisture content. Giant ragweed biomass data were converted into percent shoot biomass reduction compared with the nontreated control (Wortman 2014) as:

$$
\begin{aligned}
& \text { Percent shoot biomass reduction } \\
& \quad=[(\bar{C}-B) / \bar{C}]^{*} 100
\end{aligned}
$$

where, $\bar{C}$ is the mean biomass of the four $\bar{C}$ nontreated control replicates, and $B$ is the biomass of an individually treated experimental unit.

Statistical Analysis. Data were subjected to ANOVA using the PROC GLIMMIX procedure in SAS version 9.3 (SAS Institute Inc, Cary, NC). Data of visual control estimates of giant ragweed at 7 and 14 DAPT (Figure 1) were analyzed as randomized complete block design with preplant control methods (preplant tillage, 2,4-D, nopreplant control) year and their interactions considered as fixed effects and replication as a random effect in the model. This is because the subplot treatments (PRE/POST herbicides) were not applied at this time. The analysis of all other data was performed in split-plot design with year, preplant control methods, herbicide treatments, and their interactions considered as the fixed effects, and the replication as a random effect in the model. The treatments with zero response variables were not included in the data analysis. Before analysis, data were tested for normality of residuals using the PROC UNIVARIATE procedure. Visual estimates of giant ragweed control, density, and biomass data were arcsine square-root transformed before analysis; however, back-transformed data are presented with mean separation based on the transformed data. If the ANOVA indicated that treatment effects were significant, means were separated at $\mathrm{P} \leq 0.05$ using Tukey-Kramer's pairwise comparison test. Single degree-of-freedom contrast statements were used to compare herbicide programs with and without preplant treatment, and to compare herbicide programs with different application timings including PRE $\mathrm{fb}$ LPOST vs. EPOST $\mathrm{fb}$ LPOST. Year-by-treatment interaction was not 


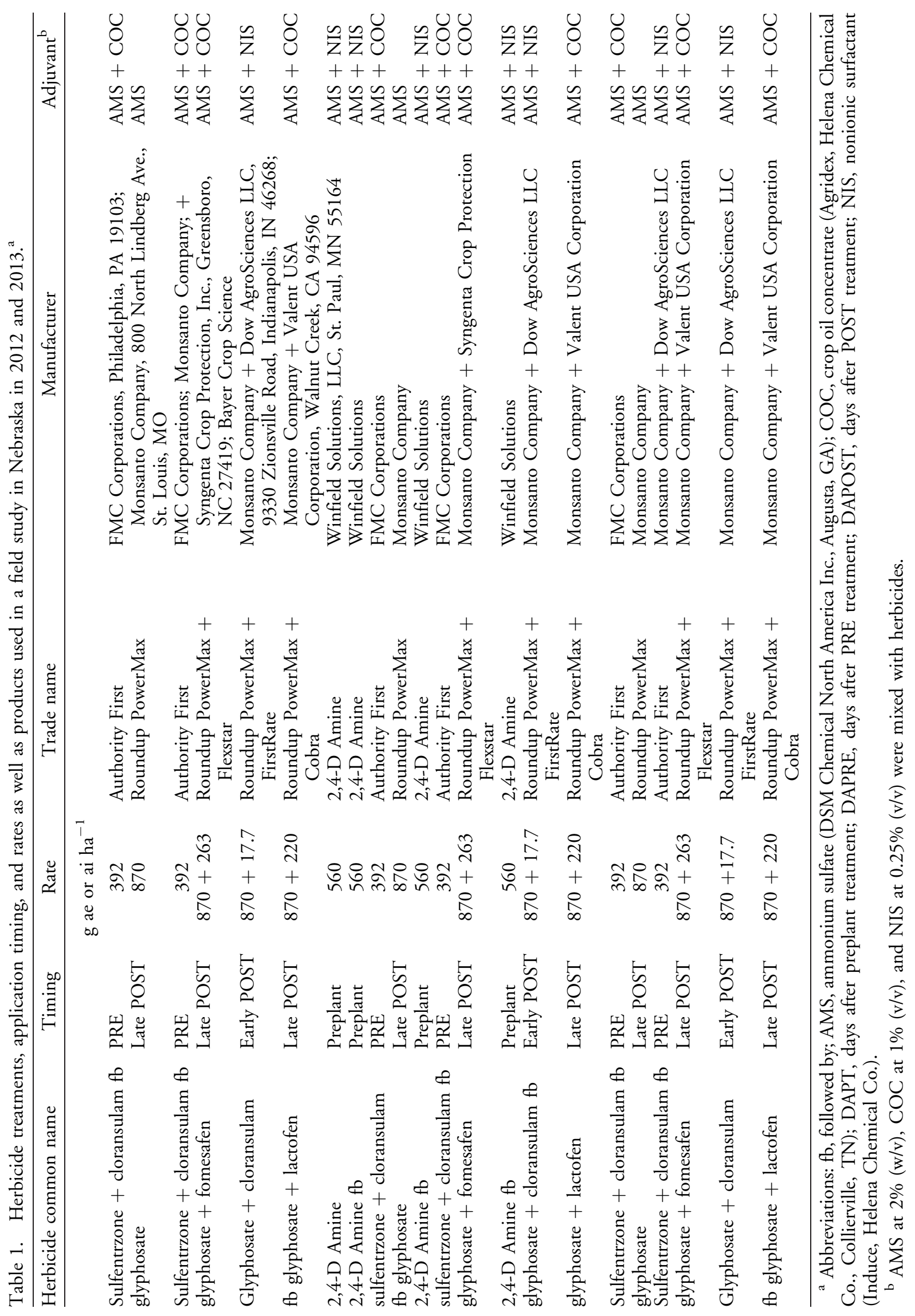




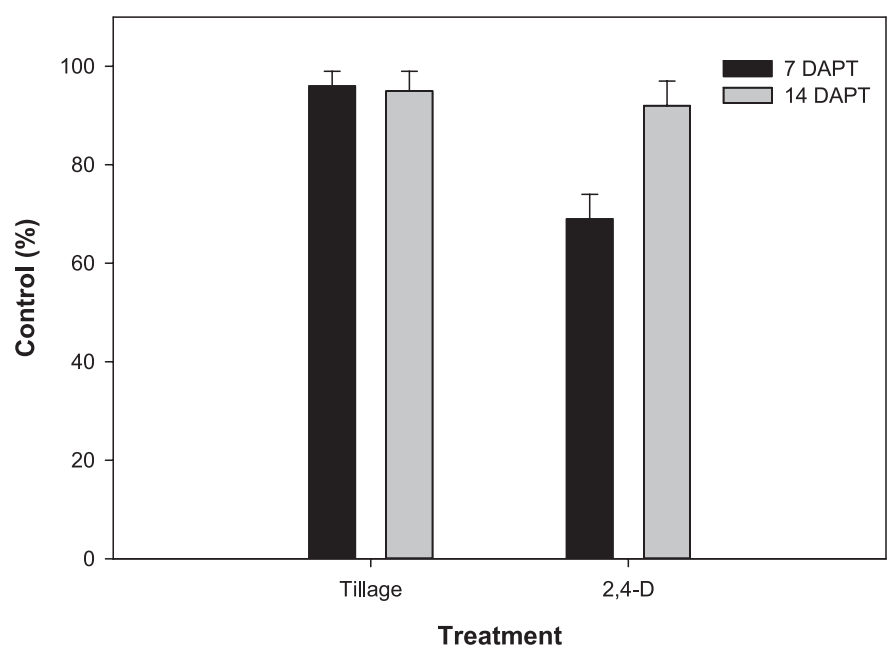

Figure 1. Control of glyphosate-resistant giant ragweed at 7 and $14 \mathrm{~d}$ after preplant treatment (DAPT) of tillage or 2,4-D in a field experiment conducted at David City, NE in 2013 and 2014. Year-by-treatment interaction was not significant; therefore, data from both years were combined. The bars with no common letter(s) are significantly different according to Tukey-Kramer's pairwise comparison test at $\mathrm{P} \leq 0.05$.

significant; therefore, data of both years were combined for variables including giant ragweed control estimates, density, and biomass.

\section{Results and Discussion}

The interaction between main plot treatments (preplant tillage, 2,4-D, no-preplant control) and subplot treatments (PRE/POST herbicides) was significant $(\mathrm{P}<0.05)$ for all variables including giant ragweed control estimates, density, and biomass. Preplant tillage or 2,4-D application provided 96 and 69\% control of glyphosate-resistant giant ragweed, respectively, at 7 DAPT. Giant ragweed control improved to $94 \%$ at $14 \mathrm{~d}$ after 2,4-D preplant application and was comparable with tillage (Figure 1). The improvement is because of systemic activity of 2,4-D and it takes about 10 to 20 $\mathrm{d}$ to fully express growth inhibition symptoms on broadleaf weeds (Kelley et al. 2005; Robinson et al. 2013). Jhala et al. (2014) reported $\leq 66 \%$ control of glyphosate-resistant giant ragweed $7 \mathrm{~d}$ after 2,4-D applied preplant, which improved to $>85 \%$ at $14 \mathrm{~d}$ after treatment. The application of sulfentrazone plus cloransulam PRE without preplant tillage or 2,4-D resulted in $<75$ and $84 \%$ control, respectively, at 7 and 21 DAPRE compared with $>96 \%$ control when preceded with preplant treatments.
The contrast analysis suggested $>95 \%$ control with preplant fb PRE programs compared with PRE-only treatments $(<85 \%)$ at 7 and 21 DAPRE (Table 2). Similarly, Kaur et al. (2014) reported $68 \%$ control of giant ragweed with sulfentrazone plus cloransulam at 7 DAPT. Ganie et al. (2015) reported $\geq 80 \%$ control of glyphosate-resistant giant ragweed with preplant tillage at $10 \mathrm{DAPT}$ in corn. Thus, results of this study emphasize the importance of preplant tillage or 2,4-D application for effective management of glyphosate-resistant giant ragweed in soybean because it resulted in $\geq 89 \%$ control regardless of PRE herbicide treatments at 7 and 21 DAPRE. Additionally, these results provided further evidence to the recommendations including preplant tillage or herbicide application made by Johnson et al. (2006) for control of emerged giant ragweed plants.

Preplant tillage or 2,4-D resulted in $<71$ and $<45 \%$ control of giant ragweed at 30 and 60 DAEPOST, respectively (Table 2). This was primarily due to the regrowth of partially controlled plants or the new emergence of giant ragweed seedlings after tillage or 2,4-D applied preplant. Similarly, Jhala et al. (2014) reported $\leq 68 \%$ control of glyphosateresistant giant ragweed at $30 \mathrm{DAPT}$ in soybean when preplant herbicide treatments were not followed by PRE or POST herbicide treatments. Preplant tillage or 2,4-D fb sulfentrazone plus cloransulam PRE $\mathrm{fb}$ glyphosate or glyphosate plus fomesafen LPOST or glyphosate plus cloransulam EPOST fb glyphosate plus lactofen LPOST resulted in $\geq 98 \%$ control of glyphosate-resistant giant ragweed at 30 and 60 DAEPOST. However, without preplant treatments, sulfentrazone plus cloransulam PRE fb glyphosate or glyphosate plus fomesafen LPOST resulted in 84 to $86 \%$ control at 30 DAEPOST, and decreased to $\leq 78 \%$ control at harvest (Table 2). A similar trend was observed at the harvest. Control of giant ragweed with preplant treatments alone reduced to $<20 \%$ (Table 2). Results indicated that $>95 \%$ control of glyphosate-resistant giant ragweed throughout the season is possible with preplant tillage or $2,4-\mathrm{D} \mathrm{fb}$ PRE or EPOST $\mathrm{fb}$ LPOST herbicide programs (Table 2). Similarly, previous research has reported that without effective preplant management, in-crop application of glyphosate tank mixture with fomesafen/bentazon/chlorimuron-ethyl or other POST-only herbicide programs provided unacceptable control of glyphosate-resistant giant ragweed (Follings et al. 
Table 2. Effect of tillage and herbicides on control of giant ragweed at 7 and $21 \mathrm{~d}$ after PRE treatment, 30 and $60 \mathrm{~d}$ after early POST treatment, and at harvest in 2013 and 2014 at David City, NE.

\begin{tabular}{|c|c|c|c|c|c|c|c|}
\hline \multirow[b]{2}{*}{ Treatment $^{\mathrm{a}}$} & \multirow{2}{*}{$\begin{array}{l}\text { Application } \\
\text { timing }\end{array}$} & \multirow[b]{2}{*}{ Rate } & \multicolumn{5}{|c|}{ Giant ragweed control ${ }^{\mathrm{b}, \mathrm{c}, \mathrm{d}, \mathrm{e}}$} \\
\hline & & & 7 DAPRE & 21 DAPRE & 30 DAEPOST & 60 DAEPOST & At harvest \\
\hline & & $\mathrm{g}$ ae or ai ha ${ }^{-1}$ & & & $-\%-$ & & \\
\hline Tillage & Preplant & - & $98 \mathrm{a}$ & $94 \mathrm{ab}$ & $70 \mathrm{c}$ & $33 \mathrm{~d}$ & $10 \mathrm{~d}$ \\
\hline Tillage $\mathrm{fb}$ & Preplant & & $98 \mathrm{a}$ & $99 \mathrm{a}$ & $99 \mathrm{a}$ & $99 \mathrm{a}$ & $98 \mathrm{a}$ \\
\hline sulfentrzone + cloransulam $\mathrm{fb}$ & PRE & 392 & & & & & \\
\hline glyphosate & Late POST & 870 & & & & & \\
\hline Tillage $\mathrm{fb}$ & Preplant & & $99 \mathrm{a}$ & $99 \mathrm{a}$ & $99 \mathrm{a}$ & $99 \mathrm{a}$ & $98 \mathrm{a}$ \\
\hline sulfentrzone + cloransulam fb & PRE & 392 & & & & & \\
\hline glyphosate + fomesafen & Late POST & $870+263$ & & & & & \\
\hline Tillage fb & Preplant & & $89 \mathrm{a}$ & $92 \mathrm{ab}$ & $98 \mathrm{a}$ & $98 \mathrm{a}$ & $98 \mathrm{a}$ \\
\hline glyphosate + cloransulam & Early POST & $870+17.7$ & & & & & \\
\hline fb glyphosate + lactofen & Late POST & $870+220$ & & & & & \\
\hline 2,4-D Amine & Preplant & 560 & $95 \mathrm{a}$ & $94 \mathrm{ab}$ & $67 c$ & $42 \mathrm{~d}$ & $16 \mathrm{~d}$ \\
\hline 2,4-D Amine $\mathrm{fb}$ & Preplant & 560 & $98 \mathrm{a}$ & 99 a & $99 \mathrm{a}$ & 99 a & $97 \mathrm{a}$ \\
\hline sulfentrzone + cloransulam $\mathrm{fb}$ & PRE & 392 & & & & & \\
\hline glyphosate & Late POST & 870 & & & & & \\
\hline 2,4-D Amine $\mathrm{fb}$ & Preplant & 560 & $97 \mathrm{a}$ & $99 \mathrm{a}$ & $99 \mathrm{a}$ & $98 \mathrm{a}$ & $98 \mathrm{a}$ \\
\hline sulfentrzone + cloransulam fb & PRE & 392 & & & & & \\
\hline glyphosate + fomesafen & Late POST & $870+263$ & & & & & \\
\hline 2,4-D Amine fb & Preplant & 560 & $94 \mathrm{a}$ & $94 \mathrm{ab}$ & $99 \mathrm{a}$ & $99 \mathrm{a}$ & $98 \mathrm{a}$ \\
\hline glyphosate + cloransulam fb & Early POST & $870+17.7$ & & & & & \\
\hline glyphosate + lactofen & Late POST & $870+220$ & & & & & \\
\hline Sulfentrzone + cloransulam fb & PRE & 392 & $74 \mathrm{~b}$ & $82 \mathrm{~b}$ & $86 \mathrm{~b}$ & $81 \mathrm{~b}$ & $78 \mathrm{~b}$ \\
\hline 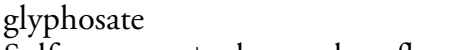 & Late POST & 870 & & & & & \\
\hline Sulfentrzone + cloransulam fb & PRE & 392 & $73 \mathrm{~b}$ & $83 \mathrm{~b}$ & $84 \mathrm{~b}$ & $80 \mathrm{~b}$ & $78 \mathrm{~b}$ \\
\hline glyphosate + fomesafen & & $870+26$ & & & & & \\
\hline $\begin{array}{l}\text { Glyphosate + cloransulam } \\
\text { fb glyphosate + lactofen }\end{array}$ & Early POST & $870+17.7$ & 0 & 0 & $77 \mathrm{bc}$ & $75 \mathrm{~b}$ & $74 \mathrm{~b}$ \\
\hline $\begin{array}{l}\text { fb glyphosate + lactofen } \\
\text { P-value }\end{array}$ & Late & $870+$ & 0.023 & 0.034 & 0.041 & 0.031 & 0.022 \\
\hline Contrasts & & & & & & & \\
\hline Preplant fb PRE vs. PRE alone & & & $\mathrm{P}<0.0001 \mathrm{I}$ & $\mathrm{P}<0.0001$ & - & - & - \\
\hline Preplant fb PRE fb LPOST vs. & & & & & & & \\
\hline PRE fb LPOST & & & - & - & $\mathrm{P}<0.0001$ & $\mathrm{P}<0.0001$ & $\mathrm{P}<0.0001$ \\
\hline $\begin{array}{l}\text { Preplant } \mathrm{fb} \text { PRE fb LPOST vs. } \\
\text { preplant fb EPOST fb LPOST }\end{array}$ & & & - & - & $\mathrm{P}<0.9000$ & $\mathrm{P}<0.9872$ & $\mathrm{P}<0.9575$ \\
\hline PRE fb LPOST vs. EPOST fb & & & & & & & \\
\hline LPOST & & & - & - & $\mathrm{P}<0.0001$ & $\mathrm{P}<0.0001$ & $\mathrm{P}<0.0001$ \\
\hline
\end{tabular}

${ }^{a}$ The experiment was arranged in a split-plot design, but to reduce the size of table main (preplant tillage, 2,4-D, no control) and subplot (PRE/POST herbicides), treatments were presented in the same column.

b Abbreviations: DAPT, days after preplant treatment; DAPRE, days after PRE; DAEPOST, days after early POST; fb, followed by.

${ }^{\mathrm{c}}$ Year-by-treatment interaction was not significant; therefore, data were combined over $2 \mathrm{yr}$.

${ }^{\mathrm{d}}$ Data were arc-sine square-root transformed before analysis; however, data presented are the means of actual values for comparison based on interpretation from the transformed values.

${ }^{\mathrm{e}}$ Means within columns with no common letter(s) are significantly different according to Tukey-Kramer's pairwise comparison test at $\mathrm{P} \leq 0.05$.

2013; Riley and Bradley 2012, 2014). However, Vink et al. (2012b) reported that sequential applications of glyphosate plus dicamba applied preplant $\mathrm{fb}$ POST resulted in $100 \%$ control of glyphosate-resistant giant ragweed in dicamba-toler- ant soybean. Moreover, the contrast statements confirmed that preplant $\mathrm{fb}$ PRE $\mathrm{fb}$ LPOST program provided $>95 \%$ giant ragweed control compared with $<87 \%$ control with PRE fb LPOST program alone, and indicated similar control with PRE $\mathrm{fb}$ 
Table 3. Effect of tillage or herbicide treatments on glyphosate-resistant giant ragweed density, biomass, and soybean yield in a field experiment conducted in 2013 and 2014 at David City, NE.

\begin{tabular}{|c|c|c|c|c|c|c|c|c|}
\hline \multirow[b]{4}{*}{ Treatment ${ }^{a}$} & \multirow{4}{*}{$\begin{array}{l}\text { Application } \\
\text { timing }\end{array}$} & \multirow[b]{4}{*}{ Rate } & & \multicolumn{2}{|c|}{ Giant ragweed $^{\mathrm{b}, \mathrm{c}, \mathrm{d}, \mathrm{e}}$} & \multicolumn{3}{|c|}{ Soybean $^{\mathrm{e}, \mathrm{f}}$} \\
\hline & & & \multicolumn{2}{|c|}{ Density } & \multirow{3}{*}{$\begin{array}{c}\text { Biomass } \\
\text { reduction } \\
60 \\
\text { DAEPOST }\end{array}$} & \multirow{3}{*}{$\begin{array}{c}\text { Injury }^{\mathrm{g}} \\
14 \\
\text { DALPOST }\end{array}$} & \multirow{2}{*}{\multicolumn{2}{|c|}{ Yield }} \\
\hline & & & \multirow{2}{*}{$\begin{array}{c}60 \\
\text { DAEPOST }\end{array}$} & \multirow{2}{*}{$\begin{array}{c}\text { At } \\
\text { harvest }\end{array}$} & & & & \\
\hline & & & & & & & 2013 & 2014 \\
\hline \multirow[b]{2}{*}{ Nontreated control } & \multirow[b]{2}{*}{ - } & \multirow{2}{*}{$\mathrm{g}$ ae or ai $\mathrm{ha}^{-1}$} & \multicolumn{2}{|c|}{-No. $\mathrm{m}^{-2}$} & \multicolumn{2}{|c|}{-\% } & \multicolumn{2}{|c|}{$\mathrm{kg} \mathrm{ha}^{-1}$} \\
\hline & & & $22 \mathrm{a}$ & $19 \mathrm{a}$ & 0 & 0 & 0 & 0 \\
\hline Tillage & Preplant & - & $8 \mathrm{~b}$ & $8 \mathrm{bc}$ & $53 \mathrm{~cd}$ & 0 & $904 \mathrm{c}$ & $656 \mathrm{c}$ \\
\hline $\begin{array}{l}\text { Tillage fb } \\
\text { sulfentrzone }+\end{array}$ & Preplant & & $0 \mathrm{~d}$ & $0 \mathrm{~d}$ & $100 \mathrm{a}$ & 0 & $2,954 \mathrm{ab}$ & $3,071 \mathrm{ab}$ \\
\hline $\begin{array}{l}\text { cloransulam fb } \\
\text { glyphosate }\end{array}$ & $\begin{array}{l}\text { PRE } \\
\text { Late POST }\end{array}$ & $\begin{array}{l}392 \\
870\end{array}$ & & & & & & \\
\hline $\begin{array}{l}\text { Tillage } \mathrm{fb} \\
\text { sulfentrzone }+\end{array}$ & Preplant & & $1 \mathrm{~d}$ & $1 \mathrm{~d}$ & $95 \mathrm{a}$ & $12 \mathrm{~b}$ & $2,881 \mathrm{ab}$ & $3,319 \mathrm{a}$ \\
\hline $\begin{array}{l}\text { cloransulam fb } \\
\text { glyphosate }+\end{array}$ & PRE & 392 & & & & & & \\
\hline fomesafen & Late POST & $870+263$ & & & & & & \\
\hline $\begin{array}{l}\text { Tillage fb } \\
\text { glyphosate }+\end{array}$ & Preplant & & $0 \mathrm{~d}$ & $0 \mathrm{~d}$ & $99 \mathrm{a}$ & $15 \mathrm{ab}$ & $2,582 \mathrm{ab}$ & $2,445 \mathrm{~b}$ \\
\hline $\begin{array}{l}\text { cloransulam fb } \\
\text { glyphosate }+\end{array}$ & Early POST & $870+17.7$ & & & & & & \\
\hline lactofen & Late POST & $870+220$ & & & & & & \\
\hline 2,4-D Amine & Preplant & 560 & $10 \mathrm{~b}$ & $9 \mathrm{~b}$ & $45 \mathrm{~d}$ & 0 & $1,178 \mathrm{c}$ & $716 \mathrm{c}$ \\
\hline $\begin{array}{l}\text { 2,4-D Amine } \mathrm{fb} \\
\text { sulfentrzone }+\end{array}$ & Preplant & 560 & $1 \mathrm{~d}$ & $1 \mathrm{~d}$ & $95 \mathrm{a}$ & 0 & $3,219 \mathrm{a}$ & $3,581 \mathrm{a}$ \\
\hline $\begin{array}{l}\text { cloransulam fb } \\
\text { glyphosate }\end{array}$ & $\begin{array}{l}\text { PRE } \\
\text { Late POST }\end{array}$ & $\begin{array}{l}392 \\
870\end{array}$ & & & & & & \\
\hline $\begin{array}{l}\text { 2,4-D Amine } \mathrm{fb} \\
\text { sulfentrzone }+\end{array}$ & Preplant & 560 & $0 \mathrm{~d}$ & $0 \mathrm{~d}$ & $98 \mathrm{a}$ & $13 \mathrm{ab}$ & $3,492 \mathrm{a}$ & $3,301 \mathrm{a}$ \\
\hline $\begin{array}{l}\text { cloransulam fb } \\
\text { glyphosate + }\end{array}$ & PRE & 392 & & & & & & \\
\hline fomesafen & Late POST & $870+263$ & & & & & & \\
\hline $\begin{array}{l}2,4-\mathrm{D} \text { Amine } \mathrm{fb} \\
\text { glyphosate }+\end{array}$ & Preplant & 560 & $0 \mathrm{~d}$ & $1 \mathrm{~d}$ & $96 \mathrm{a}$ & $15 \mathrm{ab}$ & $2,862 \mathrm{ab}$ & $2,859 \mathrm{ab}$ \\
\hline $\begin{array}{l}\text { cloransulam fb } \\
\text { glyphosate }+\end{array}$ & Early POST & $870+17.7$ & & & & & & \\
\hline $\begin{array}{l}\text { lactofen } \\
\text { Sulfentrzone }+\end{array}$ & Late POST & $870+220$ & & & & & & \\
\hline cloransulam fb & PRE & 392 & & & & & & \\
\hline $\begin{array}{l}\text { glyphosate } \\
\text { Sulfentrzone + }\end{array}$ & Late POST & 870 & $5 c$ & $3 \mathrm{~cd}$ & 89 a & 0 & $1,790 \mathrm{bc}$ & $1,480 \mathrm{c}$ \\
\hline $\begin{array}{l}\text { cloransulam fb } \\
\text { glyphosate }+\end{array}$ & PRE & 392 & & & & & & \\
\hline $\begin{array}{l}\text { fomesafen } \\
\text { Glyphosate }+\end{array}$ & Late POST & $870+263$ & $4 \mathrm{c}$ & $2 \mathrm{~d}$ & $86 \mathrm{ab}$ & $12 \mathrm{~b}$ & $1,355 \mathrm{c}$ & $1,196 \mathrm{c}$ \\
\hline $\begin{array}{l}\text { Glyphosate }+ \\
\text { cloransulam fb } \\
\text { glyphosate }+\end{array}$ & Early POST & $870+17.7$ & & & & & & \\
\hline $\begin{array}{l}\text { lactofen } \\
\text { P-value }\end{array}$ & Late POST & $870+220$ & $\begin{aligned} & 8 \mathrm{~b} \\
&<00002\end{aligned}$ & $9 \mathrm{~b}$ & $66 \mathrm{bc}$ & $16 \mathrm{a}$ & 0 & $\begin{array}{l}1,184 \mathrm{c} \\
0.041\end{array}$ \\
\hline $\begin{array}{l}\text { P-value } \\
\text { Contrasts }\end{array}$ & & & & $<0.0001$ & 0.04 & 0.008 & 0.03 & \\
\hline $\begin{array}{l}\text { Preplant fb PRE fb } \\
\text { LPOST vs. PRE } \\
\text { fb LPOST }\end{array}$ & & & $\mathrm{P}<0.0001$ & $P=0.2998$ & $\mathrm{P}<0.0001$ & - & $\mathrm{P}<0.0001$ & $\mathrm{P}<0.0001$ \\
\hline
\end{tabular}


Table 3. Continued.

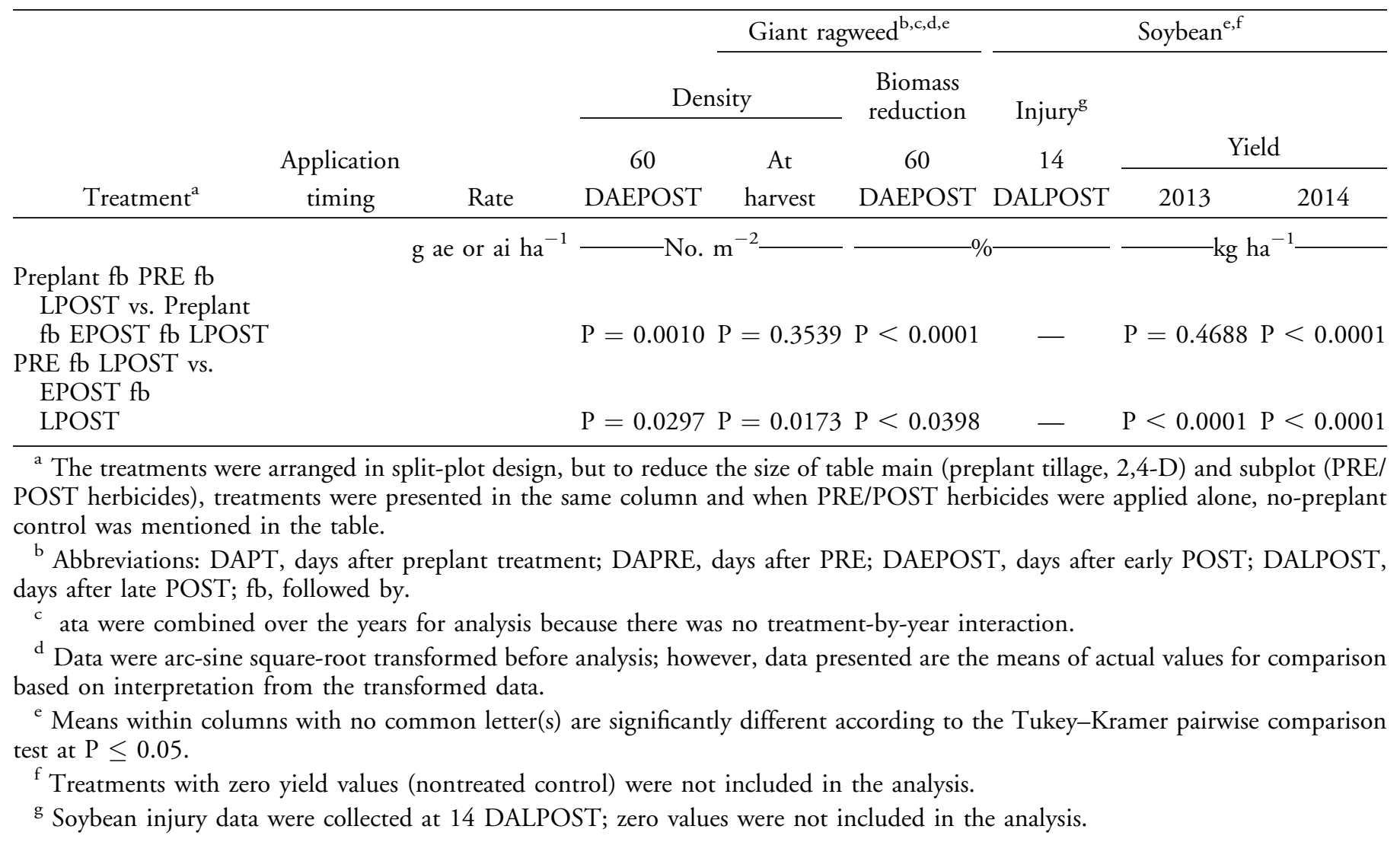

LPOST and EPOST fb LPOST programs when preceded by preplant treatments (Table 2 ).

The density and percent shoot biomass reduction of glyphosate-resistant giant ragweed reflected the results of visual control estimates. The highest density of giant ragweed (19 to 22 plants $\mathrm{m}^{-2}$ ) was recorded in the nontreated control plots compared with other treatments (Table 3). Preplant tillage or 2,4-D fb PRE or EPOST $\mathrm{fb}$ LPOST treatments resulted in a density of $<2$ plants $\mathrm{m}^{-2}$ and provided season-long control of giant ragweed (Table 3). Similarly, Kelton et al. (2013) reported a reduction of Palmer amaranth density to $\leq 4$ plants $\mathrm{m}^{-2}$ with spring tillage compared with $\geq 4$ plants $\mathrm{m}^{-2}$ without tillage in cotton. Sulfentrazone plus cloransulam PRE fb glyphosate or glyphosate plus fomesafen LPOST resulted in $\leq 5$ plants $\mathrm{m}^{-2}$ at 60 DAEPOST but was comparable with preplant tillage or 2,4-D fb PRE or EPOST $\mathrm{fb}$ LPOST programs at harvest (Table 3). Jhala et al. (2014) reported $\leq 1$ giant ragweed plant $\mathrm{m}^{-2}$ with $2,4-\mathrm{D}$ preplant fb PRE treatments.
Giant ragweed shoot biomass reduction with preplant-only treatments was $<55 \%$. However, preplant treatments $\mathrm{fb}$ PRE or EPOST fb LPOST herbicides resulted in $\geq 95 \%$ shoot biomass reduction compared with $\leq 89 \%$ reduction with PRE fb LPOST treatments. In comparable studies, 75 to $100 \%$ giant ragweed shoot biomass reduction was observed with 2,4-D or saflufenacil preplant $\mathrm{fb}$ POST application of glufosinate or ALS plus PPOinhibiting herbicides (Jhala et al. 2014; Kaur et al. 2014). Similarly, Vink et al. (2012b) reported $\geq 99 \%$ reduction in giant ragweed shoot biomass with application of glyphosate plus dicamba preplant $\mathrm{fb}$ glyphosate plus dicamba POST in dicamba-tolerant soybean. The contrast analysis indicated low giant ragweed density and high shoot biomass reduction with preplant $\mathrm{fb}$ PRE fb LPOST programs compared with PRE fb LPOST programs at 60 DAEPOST. Similarly, PRE fb LPOST programs resulted in lower giant ragweed density $\left(<5\right.$ plants $\left.\mathrm{m}^{-1}\right)$ and $>85 \%$ biomass reduction compared with EPOST fb LPOST programs, irrespective of preplant treatments (Table 3). 
Soybean injury was 12 to $16 \%$ at $14 \mathrm{~d}$ after LPOST application of fomesafen or lactofen; however, injuries were transient and had no impact on soybean yield (Table 3). Year-by-treatment interaction for soybean yield was significant probably because of differences in rainfall received during 2013 and 2014 (data not shown); hence, soybean yields are presented separately by year (Table 3). The nontreated control resulted in no soybean yield due to high giant ragweed density (19 to 22 plants $\mathrm{m}^{-2}$ ). Similarly, recent studies in Nebraska have reported $100 \%$ soybean yield loss when giant ragweed plants $\left(>15\right.$ plants $\mathrm{m}^{-2}$ ) were allowed to compete throughout the growing season (Jhala et al. 2014; Kaur et al. 2014). In 2013 no yield was harvested in the glyphosate plus cloransulam EPOST fb glyphosate plus lactofen LPOST herbicide program because of an inability to run the combine due to extreme giant ragweed competition, but a yield of $1,184 \mathrm{~kg} \mathrm{ha}^{-1}$ was recorded in 2014 in the same treatment. Preplant tillage or 2,4-D fb PRE or EPOST $\mathrm{fb}$ LPOST treatments resulted in the highest soybean yield $\left(>2,440 \mathrm{~kg} \mathrm{ha}^{-1}\right)$ compared with $<1,800 \mathrm{~kg} \mathrm{ha}^{-1}$ with the PRE fb LPOST herbicide program. Preplant tillage or 2,4-D-only treatments resulted in soybean yield $<720 \mathrm{~kg} \mathrm{ha}^{-1}$, which clearly demonstrates that preplant tillage or 2,4-D were effective for management of giant ragweed early in the season; however, follow-up application of PRE and/or POST herbicides are needed for effective season-long control of giant ragweed and to avoid yield loss. The contrast statement suggested higher soybean yield with a PRE fb LPOST program compared with an EPOST fb LPOST program irrespective of preplant treatments, except in 2013, where no differences were observed in soybean yield between PRE fb LPOST vs. EPOST fb LPOST when preceded by preplant treatments (Table 3).

This is the first report describing integrated management of glyphosate-resistant giant ragweed in glyphosate-tolerant soybean. Results from this study showed the importance of preplant control of giant ragweed with tillage or 2,4-D fb PRE/POST herbicide treatments. Jhala et al. (2014) and Kaur et al. (2014) reported an effective control of glyphosate-resistant giant ragweed with 2,4-D preplant $\mathrm{fb}$ PRE or POST herbicides. Although no literature is available on integrated management of giant ragweed with preplant tillage and herbicides, previous studies have reported an effective management of glyphosate-resistant Palmer amaranth with the integrated use of tillage and herbicides (Aulakh et al. 2013; Kelton et al. 2013).

In summary, because giant ragweed is an earlyemerging weed in Nebraska and exhibits a monophasic emergence pattern (Kaur 2015), preplant tillage is an effective tool for early-season management. The alternative approach is application of 2,4$\mathrm{D}$, particularly in no-till cropping systems. However, continuous use of 2,4-D should be avoided to prevent selection pressure, as 2,4-D-resistant common waterhemp has been confirmed in Nebraska in a continuous grass seed production system (Bernards et al. 2012). Therefore, preplant tillage would be a good alternative to include in integrated giant ragweed management programs. The potential limitations of tillage are lack of motivation for the preplant tillage, particularly among no-till growers; additional expenses; and weather, which is often not much suitable for early spring tillage.

\section{Acknowledgments}

The authors thank the Indian Council of Agricultural Research (ICAR), New Delhi, India, for partial financial support to Z.A.G. We appreciate the help of Luke Baldridge, Jordan, Moody, Mason Adams, Ethann Barnes, and Irvin Schleufer in this project.

\section{Literature Cited}

Abul-Fatih HA, Bazzaz FA (1979) Biology of Ambrosia trifida L. 2. Germination, emergence, growth and survival. New Phytol 83:817-827

Aulakh JS, Price AJ, Enloe SF, Santen EV, Wehtje G, Patterson MG (2012) Palmer amaranth management in glufosinateresistant cotton: I. Tillage system, cover crops and herbicide management. Weed Management and Herbicide Resistance Special Issue. Agronomy 2:295-311

Aulakh JS, Price AJ, Enloe SF, Wehtje G, Patterson MG (2013) Integrated Palmer amaranth management in glufosinateresistant cotton: II. Primary, secondary and conservation tillage. Agronomy 3:28-42

Bagavathiannan MV, Norsworthy JK (2012) Late-season seed production in arable weed communities: management implications. Weed Sci 60:325-334

Barnett KA, Steckel LE (2013) Giant ragweed (Ambrosia trifida) competition in cotton. Weed Sci 61:543-548

Bassett IJ, Crompton CW (1982) The biology of Canadian weeds. 55. Ambrosia trifida L. Can J Plant Sci 62:1003-1010 
Baysinger JA, Sims BD (1991) Giant ragweed (Ambrosia trifida L.) interference in soybeans (Glycine max). Weed Sci 39:358362

Bazzaz FA, Carlson RW (1979) Photosynthetic contribution of flowers and seeds to reproductive effort of an annual colonizer. New Phytol 82:223-232

Bernards ML, Crespo RJ, Kruger GR, Gaussoin R, Tranel PJ (2012) A waterhemp (Amaranthus tuberculatus) population resistant to 2,4-D. Weed Sci 60:379-384

Bloomberg JR, Kirkpatrick BL, Wax LM (1982) Competition of common cocklebur with soybean. Weed Sci 30:507-513

Clements DR, Benoit DL, Murphy SD, Swanton CJ (1996) Tillage effects on weed seed return and seed bank composition. Weed Sci 44:314-322

Coble HD, Williams FM, Ritter RL (1981) Common ragweed interference in soybeans. Weed Sci 29:339-342

Culpepper AS, York AC, Kichler J (2009) Impact of tillage on managing glyphosate-resistant Palmer amaranth in cotton. Page 1343 in Proceedings of the Beltwide Cotton Conference. San Antonio, TX: National Cotton Council of America

Davis AS, Clay S, Cardina J, Dille A, Forcella F, Lindquist J, Sprague C (2013) Seed burial physical environment explains departures from regional hydrothermal model of giant ragweed (Ambrosia trifida) seedling emergence in U.S. Midwest. Weed Sci 61:415-421

Duke SO (2012) Why have no new herbicide modes of action appeared in recent years? Pest Manag Sci 68:505-512

Ferrell JA, Witt WW (2002) Comparison of glyphosate with other herbicides for weed control in corn (Zea mays): efficacy and economics. Weed Technol 16:701-706

Follings J, Soltani N, Robinson DE, Tardif FJ, Lawton MB, Sikkema PH (2013) Glyphosate-resistant giant ragweed (Ambrosia trifida L.): 2,4-D dose response and control with postemergence herbicides in soybean. Am J Plant Sci 4:17901798

Franey RJ, Hart SE (1999) Timing of application of cloransulam for giant ragweed (Ambrosia trifida) control in soybean (Glycine max). Weed Technol 13:825-828

Ganie ZA, Sandell L, Lindquist J, Kruger GR, Mithila J, Marx DB, Jhala AJ (2015) Integrated management of glyphosateresistant giant ragweed with tillage and herbicides in corn. Page 57 in Proceedings of the 55th Annual Meeting of the Weed Science Society of America. Lexington, KY: Weed Science Society of America

Givens WA, Shaw DR, Kruger GR, Young BG, Wilson RG, Wilcut JW, Jordan DL, Weller SC (2009) Survey of tillage trends following the adoption of glyphosate-resistant crops. Weed Technol 23:162-166

Glettner CE, Stoltenberg DE (2015) Noncompetitive growth and fecundity of Wisconsin giant ragweed resistant to glyphosate. Weed Sci 63:273-281

Green JM (2014) Current state of herbicides in herbicideresistant crops. Pest Manag Sci 70:1351-1357

Harrison SK, Regnier EE, Schmoll JT, Webb JE (2001) Competition and fecundity of giant ragweed in corn. Weed Sci 49:224-229

Heap I (2015) International Survey of Herbicide-Resistant Weeds. http://www.weedscience.org/In.asp. Accessed January 20, 2015
Jhala AJ, Sandell LD, Kruger GR (2014) Control of glyphosateresistant giant ragweed (Ambrosia trifida L.) with 2, 4-D followed by pre-emergence or post-emergence herbicides in glyphosate-resistant soybean (Glycine max L.). Am J Plant Sci 15:2289-2297

Johnson B, Loux MM, Nordby D, Sprague C, Nice G, Westhoven A, Stachler J (2006) Biology and Management of Giant Ragweed. West Lafayette, IN: Purdue Extension Publication GWC-12

Johnson W, Barnes J, Gibson K, Weller S (2004) Late-season weed escapes in Indiana soybean fields. Crop Manag. http:// dx.doi.org/10.1094/CM-2004-0923-01-BR. Accessed March 26, 2015

Jordan TN (1985) Weed survey of the North Central Weed Control Conference. Pages 344-455 in Proceedings of the 42nd North Central Weed Control Conference. Las Cruces, NM: North Central Weed Science Society

Kaur S (2015) Biology and Control of Glyphosate-Resistant Giant Ragweed. M.S. dissertation. Lincoln, NE: University of Nebraska-Lincoln. $12 \mathrm{p}$

Kaur S, Sandell LD, Lindquist JL, Jhala AJ (2014) Glyphosateresistant giant ragweed (Ambrosia trifida) control in glufosinate-resistant soybean. Weed Technol 28:569-577

Kelley KB, Wax LM, Hager AG, Riechers DE (2005) Soybean response to plant growth regulator herbicides is affected by other postemergence herbicides. Weed Sci 53:101-112

Kelly AB, Mueller TC, Steckel LE (2012) Glyphosate-resistant giant ragweed (Ambrosia trifida) control in WideStrike ${ }^{\circledR}$ flex cotton. Weed Technol 26:611-616

Kelton JA, Price AJ, Patterson MG, Monks CD, Santen EV (2013) Evaluation of tillage and herbicide interaction for Amaranthus control in cotton. Weed Technol 27:298-304

Kil JH, Shim KC, Park SH, Koh KS, Suh MH, Ku YB, Suh SU, Oh HK, Kong HY (2004) Distributions of naturalized alien plants in South Korea. Weed Technol 18:1493-1495

Knezevic SZ (2015) Soybean. Pages 112-118 in Knezevic SZ, Jhala AJ, Klein RN, Kruger GR, Reicher ZJ, Wilson RG, Shea PJ, Ogg CL, eds. 2015 Guide for Weed Management in Nebraska with Insecticide and Fungicide Information. Lincoln, NE: University of Nebraska-Lincoln Extension

Loux MM, Berry MA (1991) Use of a grower survey for estimating weed problems. Weed Technol 5:460-466

Norsworthy JK, Jha P, Steckel LE, Scott RC (2010) Confirmation and control of glyphosate-resistant giant ragweed (Ambrosia trifida) in Tennessee. Weed Technol 24:64-70

Norsworthy JK, Rair D, Jha P, Scott RC (2011) Confirmation, control and physiology of glyphosate-resistant giant ragweed (Ambrosia trifida) in Arkansas. Weed Technol 25:430-435

Norsworthy JK, Ward SM, Shaw DR, Llewellyn RS, Nichols RL, Webster TM, Bradley KW, Frisvold G, Powles SB, Burgos NR, Witt WW, Barrett M (2012) Reducing the risks of herbicide resistance: best management practices and recommendations. Weed Sci (Special Issue) 60:31-62

Patzoldt WL, Tranel PJ (2002) Molecular analysis of cloransulam resistance in a population of giant ragweed. Weed Sci 50:299-305

Powles SB, Yu Q (2010) Evolution in action: plants resistant to herbicides. Annu Rev Plant Biol 61:317-347 
Rana N, Nedeljkovic D, Scott J, Sandell L, Knezevic S (2013) Glyphosate-resistant giant ragweed in Nebraska. Pages 161164 in 2013 Proceedings: Crop Production Clinics, University of Nebraska-Lincoln Extension

Regnier EE, Stoller EW (1989) The effects of soybean (Glycine max) interference on the canopy architecture of common cocklebur (Xanthium strumarium), jimsonweed (Datura stramonium), and velvetleaf (Abutilon theophrasti). Weed Sci 37:187-195

Riley EB, Bradley K (2012) Preplant herbicide options for the management of glyphosate-resistant giant ragweed in soybean. http://ipm.missouri.edu/IPCM. Accessed January 26, 2015

Riley EB, Bradley KW (2014) Influence of application timing and glyphosate tank mix combinations on the survival of glyphosate-resistant giant ragweed (Ambrosia trifida) in soybean. Weed Technol 28:1-9

Robinson AP, Davis VM, Simpson DM, Johnson WG (2013) Response of soybean yield components to 2,4-D. Weed Sci 61:68-76

Rybnicek O, Jager S (2001) Ambrosia (ragweed) in Europe. Allergy Clin Immunol Int 13:60-66

Schutte BJ, Regnier EE, Harrison SK (2012) Seed dormancy and adaptive seedling emergence timing in giant ragweed (Ambrosia trifida). Weed Sci 60:19-26

Schutte BJ, Regnier EE, Harrison SK, Schmoll JT, Spokas K, Forcella F (2008) A hydrothermal seedling emergence model for giant ragweed (Ambrosia trifida). Weed Sci 56:555-560

Shaner DL, Beckie HJ (2014) The future for weed control and technology. Pest Manag Sci 70:1329-1339

Shaw D, Culpepper SA, Owen M, Price AJ, Wilson R (2012) Herbicide-resistant weeds threaten soil conservation gains: finding a balance for soil and farm sustainability. Issue Paper 49. Ames, IA: CAST

Shrestha A, Lanini T, Wright S, Vargas R, Mitchell J (2006) Conservation tillage and weed management. http://anrcatalog. ucdavis.edu/Details.aspx?item $\mathrm{No}=8200$. Accessed March 6, 2015

Sikkema PH, Soltani N, Shropshire C, Smith PJ, Lawton MB, Tardif FJ (2009) Suspected glyphosate-resistant giant ragweed in Ontario. Proc North Cent Weed Sci Soc 64:167

Stachler JM (2008) Characterization and Management of Glyphosate-Resistant Giant Ragweed (Ambrosia trifida L.) and horseweed [Conyza canadensis (L.) Cronq.]. Ph.D dissertation. Columbus, OH: The Ohio State University. Pp 60-107

Steckel L (2007) Giant ragweed. https://utextension.tennessee. edu/publications/Documents/ W119.pdf. Accessed December 13, 2014
Swanton CJ, Shrestha A, Knezevic SZ, Roy RC, Ball-Coelho BR (2000) Influence of tillage type on vertical weed seedbank distribution in a sandy soil. Can J Plant Sci 80:455-457

Taylor JB, Loux MM, Harrison SK, Regnier E (2002) Response of ALS-resistant common ragweed (Ambrosia artemisiifolia) and giant ragweed (Ambrosia trifida) to ALS-inhibiting and alternative herbicides. Weed Technol 16:815-825

Vink JP, Soltani N, Robinson DE, Tardif FJ, Lawton MB, Sikkema PH (2012a) Glyphosate-resistant giant ragweed (Ambrosia trifida L.) in Ontario: dose response and control with postemergence herbicides. Am J Plant Sci 3:608-617

Vink JP, Soltani N, Robinson DE, Tardif FJ, Lawton MB, Sikkema PH (2012b) Glyphosate-resistant giant ragweed (Ambrosia trifida) control in dicamba-tolerant soybean. Weed Technol 26:422-428

Walsh M, Newman P, Powles S (2013) Targeting weed seeds incrop: a new weed control paradigm for global agriculture. Weed Technol 27:431-436

Webster TM, Loux MM, Regnier EE, Harrison SK (1994) Giant ragweed (Ambrosia trifida) canopy architecture and interference studies in soybean (Glycine max). Weed Technol 8:559564

Werle R, Sandell LD, Buhler DD, Hartzler RG, Lindquist JL (2014) Predicting emergence of 23 summer annual weed species. Weed Sci 62:267-279

Williams CS, Hayes RM (1984) Johnsongrass (Sorghum halepense) competition in soybeans (Glycine max). Weed Sci 32:498-501

Wilson RG (1993) Effect of preplant tillage, postplant cultivation, and herbicides on weed density in corn (Zea mays). Weed Technol 7:728-734

Wortman SE (2014) Integrating weed and vegetable crop management with multifunctional air-propelled abrasive grits. Weed Technol 28:243-252

Young BG (2006) Changes in herbicide use patterns and production practices resulting from glyphosate-resistant crops. Weed Technol 20:301-307

Zelaya IA and Owen MDK (2004) Evolved resistance to acetolactate synthase-inhibiting herbicides in common sunflower (Helianthus annuus), giant ragweed (Ambrosia trifida), and shattercane (Sorghum bicolor) in Iowa. Weed Sci 52:538548

Received June 11, 2015, and approved August 28, 2015.

Associate Editor for this paper: Kevin Bradley, University of Missouri. 